\title{
Today's Ambalat: Neglecting the Basepoints of Sipadan and Ligitan Islands for Maintaining the Equidistance Principle in the Disputed Area
}

\author{
M. Hendrapati, M. Ashri, A. Ruslan, S. Muchtar, \\ F. Patittingi, S.M. Noor, R. Hambali \& J. Sumardi"
}

The "Sipadan and Ligitan" dispute was settled by the ICJ (2002), but its impact on basepoint for baseline and maritime delimitation on the Ambalat remains a contentious issue until now. Since the islands are used as basepoints by Malaysia that results in controversy between Indonesia and Malaysia. This essay will investigate the current situation over Ambalat regarding two basepoints islands for maintaining Equidistance Line in Disputed Area. It will discuss why Malaysia has no right to use the straight baseline or straight archipelagic baseline to connect the basepoints of Sipadan and Ligitan at Sabah and suggest measures to maintain equidistance line in Ambalat.

\section{Keywords}

Neglecting, Basepoint, Straight Archipelagic Baseline, Ambalat, Maritime Delimitation, Separate Opinion.

\section{Introduction}

Sipadan and Ligitan islands are owned by Malaysia as per the International Court of Justice's ("ICJ") decision on December 16, 2002. ${ }^{1}$ In 1996, President Soeharto of Indonesian Republic and Prime Minister Mahathir Mohammad of Malaysia agreed that both would obey any decision reached by the ICJ and implement it in order to

* Marcel Hendrapati, Muhammad Ashri, Achmad Ruslan,Syamsuddin Muchtar, Farida Patittingi, Syamsuddin Muhammad Noor, Ruslan Hambali \& Juajir Sumardi. The authors are lecturers in the Faculty of Law, Hasanuddin University, Indonesia. The corresponding author is Marcel Hendrapati. He may be contacted at: marcel.hendrapati@ unhas.ac.id

1 Souvereignty over Pulau Ligitan and Pulau Sipadan (Indon. v. Malay.), Judgment, 2002 I.C.J. Rep. 263 (Dec. 17), available at http://www.icj-cij.org/docket/files/102/10570.pdf (last visited on May 3, 2017).

DOI: http://dx.doi.org/10.14330/jeail.2017.10.1.13 
ensure adherence to the rule of law relates to the status of the two disputed islands. ${ }^{2}$ The legal right of Malaysia's ownership of the islands is recognized by Indonesia through the enactment of Government Regulation Number 37 (2008), which stipulates that basepoints are not in the Ligitan Island any more, but in Sebatik Island and Karang Unarang. The ICJ's decision on the Sipadan-Ligitan case is based on the principle of 'effective occupation.' Malaysia and the predecessor state (UK) succeeded in protecting and preserving a suitable environment that can support life, and were recognized for exercising governmental functions relating to the territory. ${ }^{3}$

The principle of 'effective occupation' has often been invoked by international courts and tribunals on a variety of territorial dispute cases regarding, e.g., Palmas Island (Miangas Island) and Clipperton Island. ${ }^{4}$ The ICJ might be inspired by these precedents while deciding the sovereignty of the disputed Sipadan and Ligitan islands back in 2002.

The claim of sovereign rights by Malaysia over Ambalat could be interpreted as an attempt to extend its victory to the Sipadan and Ligitan case, considering that Malaysia holds every possible measure to gain a certain part of the Celebes Sea without paying attention to the principle of 'proportionality.' The disproportionate measures are conducted by drawing a straight baseline or archipelagic straight baseline from the points of Sipadan and Ligitan to the points of Sebatik, Sabah and Sarawak. ${ }^{5}$ These measures cause maritime boundary dispute, mainly in the Ambalat area.

The delimitation dispute involving the two States emerged on February 16, 2005, when the oil company of Malaysia (Petronas) issued an exploration concession for two oil blocks (deep-water oil concession blocks), named ND-6 and ND-7, to its subsidiary company (Petronas Carigali), ${ }^{6}$ which operates a joint venture with Shell, a part of which is owned by the Royal Dutch. (Figure 1$)^{7}$

2 Baradina, The Impact of ICJ Decision in Sipadan and Ligitan Case towards Territorial Integrity of Indonesian Republic, in The Problem of Maritime Boundary between Indonesia and Indonesian Republic in the Celebes Sea 2 (Irewati et al., eds., 2006).

3 Maritime Delimitation and Territorial Questions between Qatar and Bahrain (Qatar v. Bahr.), Judgment, 2001 I.C.J. Rep. 197 (Mar. 16), available at http://www.icj-cij.org/docket/files/87/7027.pdf (last visited on May 8, 2017).

4 M. Hendrapati, Implication of the ICJ Decision Respecting to Sipadan-Ligitan Case towards Basepoints and Maritime Delimitation, 14 InT'L J. ScI.: Basic \& Applied Res. 382-4 (2014).

5 Id. at. 148-9. See also D. Ott, PUblic International LAW IN the Modern World 117 (1987).

6 Irewati et al., supra note 2, at 130. See also I Made Andi Arsana, Ambalat Dispute Settlement through Maritime Delimitation: Geospatial and Juridical Study, 1 Scientific J. Social \& Political Sci. 48-9 (2010).

7 Id. See also G. Triggs, Maritime Boundary Dispute in the South China Sea: International Legal Issues 3 (2009). 
Figure 1: Indonesia-Malaysia Maritime Dispute

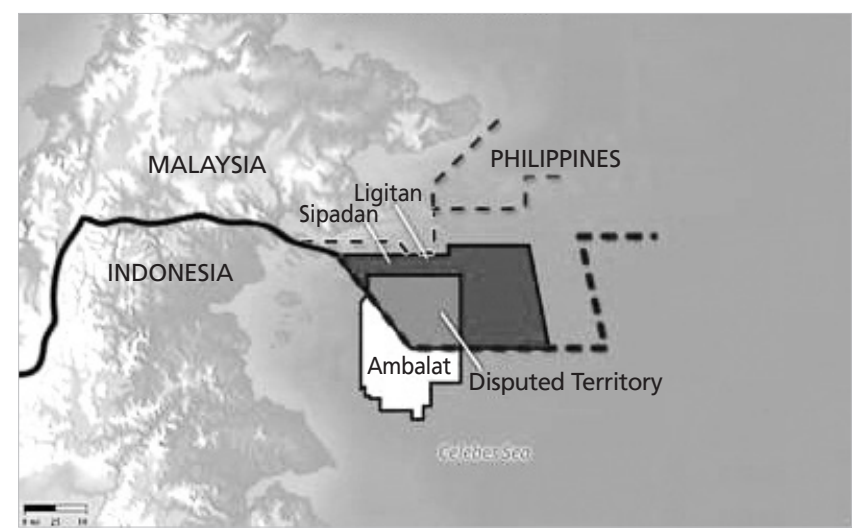

The area of the mining blocks claimed by Malaysia (ND-6 and ND-7) overlaps the mining blocks claimed by the Indonesia (Ambalat and East Ambalat), and the Government of Indonesia through Pertamina (National Oil Mining Company) had already issued exploration licenses to the Oil Company of Italy ("ENI") and the Oil Company of the US ("UNOCAL"). This area, which lies in the southern zone that is in disputation with Malaysia, is precisely located in the deepest water offshore Tarakan. ENI conducts trial drilling in the Ambalat and East Ambalat blocks to appraise the benefits which can be obtained. Such benefits, whether big or small, are discovered by appraisal drilling. Indonesia claims that the distance of the territorial waters of Malaysia is about $19 \mathrm{~km}(12 \mathrm{~nm})$ measured from Sipadan-Ligitan and a part of the concession issued by Malaysia to Shell \& Petronas Carigali overlaps the concession issued by Indonesia to ENI and UNOCAL, which began in the 1960s. The overlapping situation occurs when the two islands (Sipadan and Ligitan) are stipulated as basepoints for drawing straight baseline or archipelagic baseline connecting Sipadan and Ligitan (small islands) with Sabah and Sarawak. Because of this, the maritime delimitation dispute becomes inevitable.

This dispute indicates that every country is obliged to protect and preserve its national interest regarding vital energy supply in order to burgeon economic growth ${ }^{9}$ and the dispute over the Ambalat maritime boundary was characterized as a state of tension. An exalted Indonesian officer urged the government to take a hardline stance to the neighboring country, including a show of force towards

Id.

9 Irewati et al., supra note 2, at 131. 
it. ${ }^{10}$ Such an attitude, however, will be a threat to the regional security. It should be thus taken care of within a friendly relationship. ${ }^{11}$ At the same time, another high-ranking officer pushed the government to continue to construct a lighthouse at Karang Unarang (Unarang Shoal) under the full protection of the Indonesian Navy. This action will serve as a warning signal ensuring navigational safety and, particularly, as a mark of Indonesian ownership of Karang Unarang, offshore the Sebatik Island. Also, it implies that this natural feature could be used as basepoint to draw the straight archipelagic baseline to establish maritime delimitation based on the equidistance principle. ${ }^{12}$

Figure 2: Overlapping Oil Area

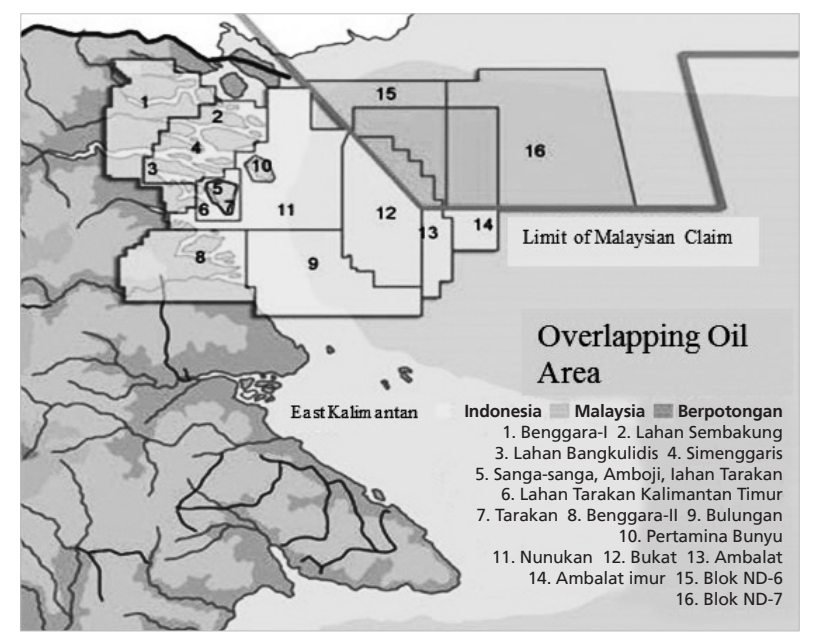

The disputed Ambalat mining block area lies in the deepest part of the sea from 500 meters to 4000 meters. ${ }^{13}$ Given that present exploration technology has already reached a depth of 2000 meters, the Ambalat area become very important, markedly since its oil was discovered to be of very high quality. The dispute over Ambalat due to the overlapping oil blocks can only be resolved by adhering to the existing procedures and provisions. It is impossible to resolve the dispute through unilateral

\footnotetext{
10 I. Parlina, RI to query Malaysian manuevers near Ambalat, JAKARTA Post, June 16, 2015, available at http://www. thejakartapost.com/news/2015/06/16/ri-query-malaysian-manuevers-near-ambalat.html (last visited on May 8, 2017).

11 E. Purwanto, Malaysia Manuever in Natuna (Manuver Malaysia di Natuna), Daily Kompas 15 (2005).

12 Irewati et al., supra note 2, at 130. See also Arsana, supra note 6.

13 Id. See also Triggs, supra note 7 , at 3.
} 
means, as attempted by Malaysia in 2004.

In order to solve the maritime delimitation line question, we hereby propose for neglecting and refusing the function of the two small islands of Malaysia as basepoints. The refusal concept could be used as an input by the Indonesian authority when the maritime delimitation in the Ambalat conflict area is to be negotiated. This concept is relevant as a measure to prevent the loss of Indonesian waters in the conflict area. Therefore, the Indonesian authority must ensure that Malaysias unfair use of the two islands in constructing the maritime delimitation line on the overlapping area does not stand. The case of Sipadan and Ligitan should serve as an example to the Indonesian people and government, ${ }^{14}$ due to Indonesia's tolerance to Malaysia's excuse of maintaining the lighthouse offshore the two islands. Nevertheless, the lighthouse was essentially constructed by the Netherlands, not by the UK. ${ }^{15}$

Various factors are influencing the negotiations of maritime delimitation line in the Ambalat block. If the maritime delimitation is negotiated and agreed reciprocally, then the problem is settled and finalized. In reality, however, as the positions of the two parties are opposite, it is difficult to achieve a solution, at least within a short time. If the maritime delimitation line is not achieved, then any alternative solution will be opened to attempt. Indonesia and Malaysia can establish their overlapping claims either totally or partly in a joint development zone ${ }^{16}$ as both the nations have many experiences on it. Indonesia has carried out a highly complicated Timor Gap area with Australia, a part of which was taken over by Timor Leste State (Timor Lorosae State). Malaysia conducts joint development with Thailand and Vietnam in Malacca Straits and Natuna Sea. Nevertheless, Indonesia refused an offer from Malaysia in 2006 to conduct a joint venture of oil and gas resources exploration in a certain part of Ambalat block. Ex-Prime Minister Abdullah Ahmad Badawi of Malaysia finally admitted that the maritime delimitation problem in the Ambalat block could not be easily settled. ${ }^{17}$

The government of Malaysia proposed to commit to a joint venture between Petronas (Malaysian oil company) and Pertamina (Indonesian oil company) in Ambalat, ${ }^{18}$ hoping that the dispute and difference of perception will not hamper the two parties from exploring cooperation opportunity in the Ambalat waters.

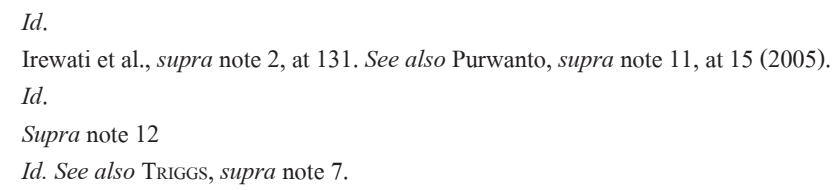


But the former Foreign Minister of Indonesian Republic, Hassan Wirayuda refused the cooperation proposal, since Indonesian was interested in giving priority to the settlement of the permanent maritime delimitation. ${ }^{19}$ As long as the maritime delimitation agreement has not been setteled following the Sipadan-Ligitan case, Indonesia is reluctant to discuss the management cooperation for the oil and gas existing in the Ambalat.

Further development concerning the maritime delimitation settlement measures was unfolded on December 17, 2010. Then, the Indonesian government through Pertamina addressed that Petronas had become a partner of Pertamina, and a Memorandum of Understanding regarding the partnership in the block of East Natuna was signed. ${ }^{20}$ Although the Indonesian government tried to stifle the escalation of the maritime delimitation line dispute in the Ambalat area with this action, Malaysia was inclined to be uncooperative and self-confident, especially after its victory in the Sipadan and Ligitan case. ${ }^{21}$ Actually, Malaysia participated in the Petronas project at the block of East Natuna in order to obtain benefits in the region of South China Sea. Nevertheless, shortly after the MoU was concluded, Malaysia withdrew from it because the block of East Natuna is not a priority of Petronas anymore. Petronas was losing its interest in the block of East Natuna because of (1) the decreased oil price in the global market and (2) the production expenditure of the East Natuna block field, which is higher than that of other fields(the block is located in deep water). ${ }^{22}$

Since the withdrawal of Malaysia, Indonesia has become more vigilant and cautious of any possible geopolitical manoeuvre made by Malaysia. Despite the decreased oil price in the international market, Malaysia tends to conduct oil exploration anticipating that oil resources will become scarcer in the future and then their prices will soar. ${ }^{23}$ Malaysia seems to claim Ambalat once more because a greater part of the natural resources contained in the Ambalat block consists of oil resources that are beneficial. In 2015, Malaysia conducted nine violations of the Indonesian air territory of Ambalat on the eastern side, offshore Kalimantan. These illegal flights were carried out whenever Malaysia found out that the Indonesian

19 F. Hutapea, House Commission Urges Unified Response Over Ambalat Dispute, JaKarta Globe, Feb. 26, 2017, available at http://jakartaglobe.beritasatu.com/.../house-commission-urges-unified-response-over-ambalat-dispute (last visited on May 8, 2017).

20 Purwanto, supra note 11.

21 Id.

22 Irewati et al., supra note 2, at 131.

23 Supra note 20. 
military aircrafts were not present in the air base of Tarakan and Makassar. ${ }^{24}$ These violations to the Indonesian air territory (since 2015) would rather imply that Malaysia has the ambition of assigning a significant role to Sipadan and Ligitan. ${ }^{25}$ It is presumed that the intended role is to use these two islands as basepoints to draw straight archipelagic baseline connecting Sipadan-Ligitan and Sabah Island, the length of which exceeds $100 \mathrm{~nm}$. This situation should not be allowed since Malaysia has no right to use the straight archipelagic baseline because it is a continental State, not an archipelagic State.

\section{Discussion}

The ICJ in its decision on Sipadan and Ligitan case ${ }^{26}$ addressed that Malaysia has sovereignty over Sipadan and Ligitan on the basis of effective occupation. Malaysia can legitimately perform or exercise the governmental administration function related to the two islands concerned, such as constructing and maintaining the lighthouses, creating and enacting various law regulations. ${ }^{27}$

The Court decision, however, is accompanied by a dissenting opinion submitted by Judge Thomas J. Franck and a separate opinion by Judge Shigeru Oda. ${ }^{28}$ Shigeru Oda stated, inter alia, that even though Malaysia was awarded the sovereignty over the two islands, the benefit would not impact on maritime line delimitation between the two States. ${ }^{29}$ Although these two islands are owned by Malaysia this should not have any impact on the maritime delimitation, since the maritime delimitation line could be drawn regardless the two islands themselves. Judge Oda was suspicious of Malaysia's motive behind its claim to the two islands. According to Judge Shigeru

24 Purwanto, supra note 11, at 15.

25 A. Pratama, Indonesian Army is Anggry, Malaysia's Military Aircraft Enters Ambalat 9 Times (TNI Geram, Pesawat Tempur Malaysia Masuk Ambalat 9 Kali)<available only in Malay language> CNN INDONESIA, June 17, 2015.

26 Supra note 1 , 935.

27 Y. Tanaka, Predictability and Flexibility in the Law of Maritime Delimitation 9 (2006). See also supra note 1, at 263.

28 In Judge Oda's view, the issue of sovereignty arose only as a result of the Parties'manoeuvring for better bargaining positions in the continental shelf delimitation. The question remains how 'equitable' considerations apply to these islands. Judge Oda concludes that the present Judgment does not necessarily have a direct bearing on the delimitation of the continental shelf. See supra note 1.

29 Id. at. 690. In conclusion, the authors would submit that the present Judgment determining sovereignty over the islands does not necessarily have a direct bearing on the delimitation of the continental shelf, which has been a subject of dispute between the two States since the late 1960s. 
Oda, the case of Sipadan-Ligitan should be a weak one, since the respective parties did not provide any strong evidence to claim the right of the two islands. ${ }^{30}$ His separate opinion does essentially contain values of goodness, wisdom, honesty and justice in relation to the maritime delimitation. He implicitly said that the continental shelf or exclusive economic zone boundary delimitation on the disputed area should not be done since, based on special circumstances rule, a delimitation line could well have been drawn disregarding these two extremely small, socially and economically insignificant islands. ${ }^{31}$

On one hand, the Indonesian Republic has already implemented the special agreement by ratifying it in 1997 and relinquished ownership (sovereignty) of Sipadan and Ligitan to Malaysia according to the ICJ decision. The Indonesian government totally honored and obeyed the ICJs decision because it was final and compulsory on the basis of the special agreement. Indonesia believes in the values of the separate opinion of Judge Oda, despite the fact that Article 61 of the ICJ Statute gives Indonesia the right to apply for a revision. Malaysia should recognize these values and implement them as well because the separate opinion is an integral part of the ICJ decision which should be honored, obeyed and carried out as a good neighboring country.

Malaysia needs to observe self-introspection to understand its status in the United Nations Convention on the Law of the Sea ("UNCLOS") context as a normal coastal or continental State, which can only apply normal baseline. Article 7 of the UNCLOS prohibits Malaysia from using straight baseline whose coast is not deeply indented. Malaysia's geographical condition is not similar to that of Norway in the Anglo-Norwegian Fisheries Case. ${ }^{32}$ These principles have been incorporated into Article 5 of the 1958 Geneva Convention on the High Seas and Article 7 of the UNCLOS. Malaysia is an archipelagic State. Article 46 of the UNCLOS stipulates that an archipelagic State consists of one archipelago or more and does include other islands. An archipelago is a group of islands including all parts of the islands, the waters existing between the islands and other natural features, including drying reefs, which are closely interrelated so that all the components constitute a single entity from the geographical, economic, political and historical points of

30 Id. at. 687.

31 See Declaration of Judge Od, at 689-90, available at http://www.icj-cij.org/docket/files/102/7716.pdf (last visited on May 8, 2017). This resulted from a misconception on the part of the Parties, who failed to understand that, in accordance with the 'special circumstances' rule, a delimitation line could well have been drawn disregarding these two extremely small, socially and economically insignificant islands.

32 Anglo-Norwegian Fisheries (U.K. v. Nor.), Judgment, 1951 I.C.J. Rep. 133, 2 (Dec. 18), available at http://www. icj-cij.org/docket/files/5/1809.pdf (last visited on May 8, 2017). 
view. ${ }^{33}$ Malaysia clearly does not comply with the principles mentioned above. Therefore, based on Article 47, it is not entitled to use the archipelagic straight baseline connecting the two islands and its territory in Sebatik, Sarawak and Sabah. Accordingly, Judge Oda opined that Malaysia's ownership of the two islands would not have any impact on maritime delimitation in the Ambalat area. ${ }^{34}$ Nevertheless, in reality, this separate opinion is disrespected by Malaysia, since it did draw the line connecting the two islands to Sebatik, Sarawak and Sabah. The (archipelagic) straight baseline goes more than $100 \mathrm{~nm}$ in length, particularly connecting the two islands and northern Sebatik. The implication of such action is an appropriation of the disputed area of the Ambalat block.

Indonesia has already shown its respect and obedience to the ICJ decision through the enactment of Government Regulation Number 37 (2008) regarding the Revision of Government Regulation Number 38 (2002) with reference to the Geographical Coordinate List of the Basepoints for Indonesian Archipelagic Straight Baselines. This Government Regulation is aimed at ensuring adherence to the rule of law by Indonesia's obedience and implementation to the ICJ decision awarding Malaysia the sovereignty over the two islands. Through this regulation, the outermost islands of Indonesia, being the basepoint in the boundary area, are not Ligitan Island, but Karang Unarang and southern Sebatik.

Although Sipadan and Ligitan islands have been taken over to Malaysia on the basis of the ICJ decision 2002, while negotiating the delimitation of the continental shelf or exclusive economic zone in certain parts of Celebes Sea, which are regarded as overlapping by Malaysia, Indonesia referred to the Romania v. Ukraine case, in which the ICJ stated that an island called Serpents Island could not be used as basepoint for establishing the maritime boundary in the Black Sea. ${ }^{35}$ In this judgment, the Court adjudicated that the median line or equidistance line principle should be applied for the maritime boundary delimitation between Romania and Ukraine without considering the presence and existence of Serpents Island that is owned by Ukraine but closer to Romania's territory. ${ }^{36}$ In addition, there are many bilateral agreements concluded by neighboring countries ignoring a small island

33 The definition of archipelago has been improved on the basis of the issue of the South China Sea, concerning some natural features, like rocks, drying reefs, low tide elevation existing in the Spratly archipelago disputed by five States.

34 Government Regulation Number 38 (2002), equipped with Annex specifying 167 Outermost Island of Indonesia, including Natural Features, like Rock, etc.

35 Maritime Delimitation in the Black Sea (Rom. v. Ukr.), Judgment, 2009 I.C.J. Rep. 3 (Feb. 3) available at http:// www.icj-cij.org/docket/index.php?p1=3\&p2=2\&PHPSESSID $=$ fcccb $763 \mathrm{fd} 140 \mathrm{~d} 1 \mathrm{~d} 3 \mathrm{dadd} 47 \mathrm{cbb} 59$ ee $2 \mathrm{~b} \&$ case $=$ $132 \&$ code $=$ ru\&p3=4 (last visited on May 8,2017 ).

36 Id. at 4. See also Y. Tanaka, The International Law of the Sea 201-5 (2012). 
as basepoint. As a result, such islands do not impact the maritime delimitation. All the bilateral agreements and the Romania/Ukraine case have no influence to small island belong to Ukraine that can be used as references by the Indonesian authority during negotiation regarding the maritime boundary delimitation in the Ambalat territory.

The use of Sipadan and Ligitan as basepoints for drawing the baseline may be discovered in Malaysia's map 1979 and Laws regarding the Exclusive Economic Zone 2007. Malaysia's laws use a nomenclature known as 'baseline,' but, in fact, the baselines mentioned in the act of the country are implemented by drawing straight archipelagic baselines or straight baselines. ${ }^{37}$ Archipelagic baselines should only be used or applied by an archipelagic state. Malaysia is obviously not an archipelagic, but a continental or normal coastal State. Therefore, it is not entitled to use or apply straight baselines connecting the basepoint of the two small islands and the basepoint of Sebatik and Sabah, as stipulated in Article 47 of the UNCLOS. As Malaysia's coast line is clearly but not deeply indented, it does not have any right to use or apply straight baselines, as stipulated in Article 7 of the UNCLOS.

Indonesian Republic should take any possible measure to ensure that the status of the two islands owned by Malaysia after the ICJ decision has no legal effect related to drawing straight baselines on the basis of the following legal reasons. First, the east territory of Malaysia (Sarawak, Sabah and Sipadan-Ligitan) would possess a group of islands and its coast is not deeply cut into. Second, geographically, as Malaysia is a normal coastal or continental State, not an archipelagic State, it is unreasonable for it to draw an archipelagic straight baseline from Sipadan to Sebatik.

Ignoring the use of the two islands as basepoints, Indonesia instead invoked a principle called "special or relevant circumstances," which embraces both geographical factors (the coast configuration, the presence or existence of an island, and the proportionality principle) and non-geographical factors (the historical right and economic consideration related to Malaysia's economic condition). ${ }^{38}$ These factors are frequently used in various international agreements such as the 1989 Agreement between Australia and Indonesia (Timor Gap), which established a zone of cooperation aimed at neglecting the use of islands as basepoints for drawing the archipelagic straight baseline. If the role of these islands as basepoints is successfully neglected for drawing a baseline, it would automatically eradicate the role of the two islands in constructing equidistance line as maritime boundary line on the Ambalat area.

37 Hendrapati, supra note 4, at 382-4.

38 TANAKA, $i d$, at 208-10. 
It is necessary to understand that the factors mentioned as relevant circumstances have an open-ended ambit and do not have any closed list ${ }^{39}$ in relation to the maritime boundary delimitation. Hence, such factors would be optimized for neglecting and eradicating the role of the islands as basepoints for drawing the archipelagic straight baseline. Through optimizing the relevant circumstances principle, as asserted in the Separate Opinion of Judge Oda, the various negotiations between the two States must be focused on neglecting and eradicating the role of the islands not only as basepoint for drawing the straight baseline connecting the two islands Sebatik, Sabah and Sarawak, but also establishing, constructing and adjusting the equidistance line for the maritime boundary of Ambalat area, both before and after the ICJ decision. Here, the concept of equidistance line is important as long as the maritime boundary delimitation is not yet under any agreement.

On the basis of international customary law, the parties are not prohibited from implementing the equidistance line, which is parallel to any coastal line. The implementation of the equidistance line principle based on international customary law can be discovered through the Dissenting Opinion of Judge Tanaka in the North Sea Continental Shelf cases in 1969. ${ }^{40}$ Judge Tanaka states that although West Germany did not ratify the 1958 Geneva Convention on the Continental Shelf, Germany has a duty to implement the equidistance line provision, stipulated in the Convention on the basis of international customary law. Since the provision of equidistance line during the Convention was developed into international customary law, which is binding on all States, whether parties or not. ${ }^{41}$ Tanaka maintained:

The character of 'general principles of law' is more notably to be recognized in the principle of equidistance than in the alleged principle of just and equitable apportionment. I consider that the legislative process of the Geneva Convention and, parallel with it, the formation of customary international law on the matter of the equidistance principle indicate the existence of a principle or method of a technical, therefore universal character on this matter as a common denominator for conventional law or customary law. My conclusion is that the application of the principle of equidistance is not overruled by the principle of just and equitable apportionment or delimitation. The reference of the Federal Republic to natural law doctrine or the

39 M. Hendrapati, Malaysia Has No Right to Ride in the Archipelagic State Principle (Malaysia Tidak Dapat Menumpang Pada Azas Negara Kepulauan), 1 InT’L L. J. JuRISDICTIONARY 15-7 (2005).

40 Z. Samin, The binding force of Treaty towards Third State (or State not Party) (Daya Mengikat Perjanjian Internasional terhadap Negara bukan Peserta), 2 Padjadjaran J. L. \& Social Sci. 57-8 (1981).

41 North Sea Continental Shelf (F.R.G. v. Den.), Judgement, 1969 I.C.J. Rep. 194-5 (Feb. 20), available at http:// www.icj-cij.org/docket/files/51/5553.pdf (last visited on May 2, 2017). 
general principles of law is out of place. ${ }^{42}$

Karang Unarang (the basepoint for drawing the archipelagic straight baseline connecting this natural feature) is offshore the Sebatik Island and can be classified as a low tide elevation. When the Ambalat case was released, the Indonesian authority successfully constructed a lighthouse on Karang Unarang which is owned by Indonesia. The Indonesian Navy should keep securing the lighthouse at Karang Unarang, adjacent to the Ambalat area, as well as the maritime boundary based on the equidistance line in the Ambalat area. Karang Unarang and the southern Sebatik always need the presence of the Indonesian Navy in order to prevent shrinkage and reduction of the national maritime territory in the Celebes Sea. ${ }^{43}$

The role given to the two islands is disproportionate because the correlation between the length of Malaysia's coastal line and its water area yields a ratio beyond one to nine, which is unreasonable, unworthy and unjust. ${ }^{44}$ The baseline drawn from the two islands to the northern Sebatik or Sabah, as stipulated in Law on the Exclusive Economic Zone of Malaysia 2007, is unequal to Malaysia's claim over the marine area. Hence, the law is contrary to the proportionality principle. In this context, irrespective of the nomenclature, the maritime diplomacy of Indonesia should be focused on the negligence or eradication of the use of Sipadan and Ligitan as base points for drawing any baseline. Any shift and adjustment of the existing equidistance line, being attempted by Malaysia after the ICJ decision regarding Sipadan and Ligitan, must be neglected and eradicated as well, because they would be contrary to the proportionality principle. The concept of negligence or eradication would be to ensure the stability of the equidistance line such as the maritime boundary line on the continental shelf and exclusive economic zone, mainly in the Ambalat area. ${ }^{45}$

Essentially, the idea of negligence or eradication of the basepoints of the two islands should be regarded as the implementation of the ICJ decision 2002, particularly that of Judge Oda's declaration, who fundamentally did not want any shift or adjustment of maritime boundary line after the victory of Malaysia. ${ }^{46}$ Moreover, the

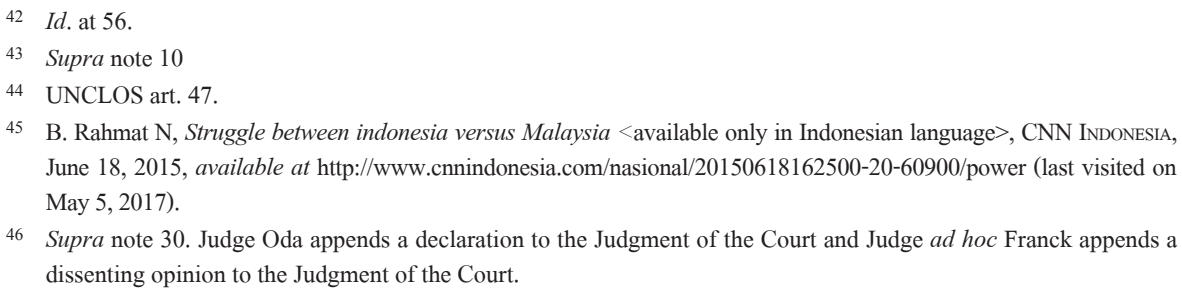
June 18, 2015, available at http://www.cnnindonesia.com/nasional/20150618162500-20-60900/power (last visited on May 5, 2017).

46 Supra note 30. Judge Oda appends a declaration to the Judgment of the Court and Judge ad hoc Franck appends a dissenting opinion to the Judgment of the Court. 
negligence or eradication concept is significant because it agrees with the purpose of the law, including the purpose of the concerned ICJ decision, particularly to achieve distributive justice ${ }^{47}$ in the case and to obtain a clear equilibrium between what the Indonesian Republic gets from Malaysia in reality and what Malaysia should give to Indonesia. $^{48}$

Considering that Indonesia has already recognized Malaysia as the owner of the two islands, Malaysia should also honor, obey and implement the ICJ decision absolutely, including the moral message in the Separate Opinion of Judge Oda. Malaysia has already been exercising its sovereignty over the two islands which are now expensive tourist destinations. Thus, it should also comply with the substance of the same decision through negligence or eradication of the use of the two islands as basepoints. Consequently, there is no need to shift or adjust the equidistance principle for establishing the maritime boundary line on the continental shelf or exclusive economic zone, especially in the Ambalat area. It will be the best way to achieve justice for the respective States.

\section{Conclusion}

The use of negligence or eradication of the two islands as basepoints is closely related to the geographical and legal status of Malaysia as a continental State, which only has the right to draw a normal baseline. As long as Malaysia is not classified as an archipelagic State under the UNCLOS system (geographically, its territory has continental characteristic), it is not qualified to draw and implement straight baseline or archipelagic straight baseline from Sipadan and Ligitan to Sabah and Sarawak. Furthermore, the proposed concept of negligence or eradication was essentially originated from the values implied in the declaration of Judge Oda. Eventually, any shift or adjustment of the maritime boundary based on the equidistance line in the disputed area should be prevented without any agreement regarding the boundary line of the continental shelf or exclusive economic zone. Each party must implement and maintain the equidistance principle.

The presence of the Indonesian Navy, the intensive acquisition of science and technology, and the efforts of renascence of nationalism and patriotism through the prosperity approach largely exist in the boundary area, where all constitute condition

47 B. Bix, A Dictionary of Legal Theory 55 (2004).

48 S. Ratnapala, Jurisprudence 320-3 (2009). 
296 M. Hendrapati et al.

sine qua non in the frame of guarding and securing the maritime boundary based on the equidistance line in the Ambalat disputed area. 